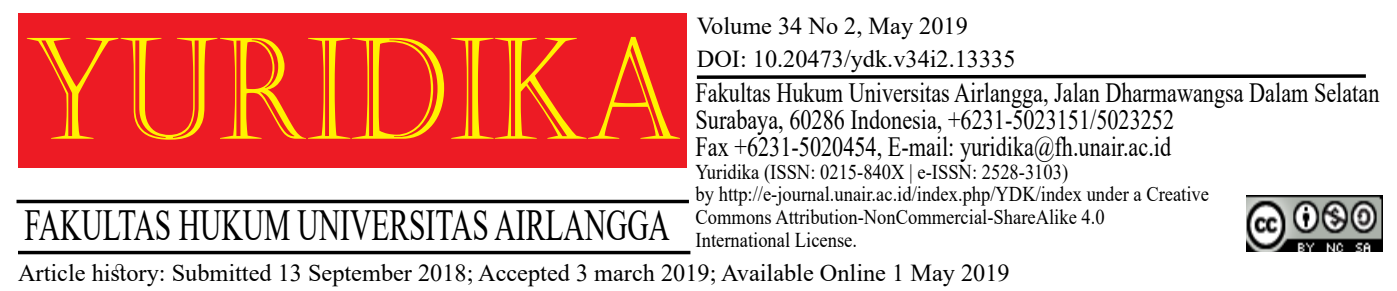

\title{
Integrating Farmers' Rights to Equitable Benefit Sharing Into the Malaysian Plant Variety Law: Learning from Others
}

\author{
Murshamshul Kamariah Musa, Abdul Majid Tahir Mohamed \\ and Abdul Majid Hafiz Mohamed* \\ msham@unisza.edu.my \\ Universiti Sultan Zainal Abidin, Terengganu
}

\begin{abstract}
The International Treaty on Plant Genetic Resources for Food and Agriculture (FAO Treaty 2004), articulated four core rights under the Farmers' Rights conceptnamely the right to traditional farming knowledge, the right to seed, the right to equitable benefit sharing and the right to participate in decision making process. Article 9.2 (b) of FAO Treaty 2004 stipulates that farmers should be given equal opportunity to equitably participate in sharing benefits from the use of plant genetic resources for food and agriculture. The right to equitable benefit sharing legally justifies among others, the rights of small holder farmers who have been breeding seeds for generations to receive benefits; either monetary or non-monetary from any commercialization of the seeds that have been developed by them. This paper investigates to what extent the existing legal provisions of plant variety law in Malaysia has integrated this right to equitable benefit sharing to small farmers as compared to similar legislations in India and under African Union (AU Model Law for the Protection of the Rights of Local Communities, Farmers and Breeders, and for the Regulation of Access to Biological Resources). These two legal framework aimed to protect their small farming communities are cited as legislations with the best practices on implementing Farmers' Rights core rights. The aim is for Malaysia to learn from these countries in order to ensure legal protection for small farmers' right to equitable benefit sharing of their plant genetic resources. The research is a doctrinal research of comparative legal provisions.
\end{abstract}

Keywords: Farmers' Rights; Plant Variety Law; Access and Benefit Sharing; FAO Treaty; Malaysia.

\section{Introduction}

This article discusses on the right of access and benefit sharing as enumerated by the Farmers' Right concept in the International Treaty on Plant Genetic Resources

* This study is funded by a research grant No. UNISZA/2017/DPU/51 Provided by Universiti Sultan Zainal Abidin. 
for Food and Agriculture 2004 (FAO Treaty). In the course of the research, qualitative method was adopted, making full use of the library doctrinal research. Analysis was made of relevant statutory provisions, reports as well as relevant policies affecting the farmers' right to access and benefit sharing of the commercial utilization of plant genetic resources under the relevant plant variety law in Malaysia, India the African Union Model Law. Being of a comparative study between the plant variety laws under three separate legal frameworks, the article concludes with a brief summary of the extent of inclusion on the right of equitable access and benefit sharing for farmers under the plant variety law of Malaysia and related legal framework.

The International Treaty on Plant Genetic Resources for Food and Agriculture 2004 (FAO Treaty) acknowledged the important role farmers played in the historical development and contemporary conservation of plant genetic resources for food and agriculture (PGRFA) under Article 9 of the Treaty. This particular provision laid down the four core components of Farmers' Rights and provides specific guidance on the basic measures to promote and protect rights of farmers. These are the right to save and sell seed, the right to traditional knowledge, the right to participate in equitable benefit-sharing and the right to participate in decisionmaking processes. Malaysia has ratified both the FAO Treaty and Convention on Biological Diversity (CBD) as part of its international commitments. ${ }^{1}$ Both of these international instruments recognize the contribution of farmers towards conservation and development of plant genetic resources. This comparative analysis will analyse the provisions of the Malaysia's existing legislative provisions on plant variety law, with those in India and also AU Model Law to what extent the Malaysian Protection of New Plant Varieties Act 2004 (PNPV) has created inroads towards protection and recognition of the rights of farming communities in Malaysia on the farmers' rights to equitable benefit sharing.

\section{Incorporating Farmers' Right Concept at National Level}

\footnotetext{
${ }^{1}$ See under List of Multilateral Treaty entered by Malaysia under the official website of Ministry of Foreign Affairs, Malaysia at www.kln.gov.my.
} 
Malaysia was obliged to protect plant varieties under a sui generis system or a system which combines both patent and sui generis as mandated by Article 27.3 (b) of TRIPS. In furtherance of this obligation, Malaysia enacted the Protection of New Plant Varieties Act in 2004. Given that Malaysia is not a member of UPOV, there is no requirement to enact PVP legislation according to the requirements of either of the UPOV Conventions of 1978 or 1991. Malaysia has in fact chosen to emulate India's ${ }^{2}$ sui generis formula by recognising the contributions of local indigenous and traditional farming communities in its plant variety legislation. Both plant variety protection system and plant breeders' rights are regulated by this Act, which is supplemented by the Protection of New Plant Varieties Regulations 2008. The working of the Act is further complemented by a set of administrative guidelines to assist in regulating procedures and registrations of new plant varieties. ${ }^{3}$ The purpose envisioned for the Act is to encourage farmers to make full use of their genetic resources while encouraging the private sector to release new plant varieties suitable for the Malaysian agricultural sector. Malaysia does not have a specific legislation catering to farmers' rights, nonetheless, few provisions under the plant variety law incorporated certain core rights as listed under the Farmers' Rights concept in the FAO Treaty 2004.

India is considered particularly important in discussions ${ }^{4}$ on the development of a legal framework for Farmers' Right as it is among the first countries to adopt extensive legislation on Farmers' Rights. The Protection of Plant Varieties and Farmers' Rights Act 2001 (PPVFR 2001), which provides simultaneous legal protection for both breeders and farmers, is considered unique

${ }^{2}$ Ida Madieha Abdul Ghani Azmi, 'The Protection of Plant Varieties in Malaysia' (2004) 7 Journal of World Intellectual Property.[878-889].

${ }^{3}$ See the Department of Agriculture, Malaysia website information on the plant variety protection system in Malaysia at http://pvpbkkt.doa.gov.my. The guidelines are known as Administrative Guidelines on Application and Registration of New Varieties of Plants 2008 which has to be read simultaneously with both the Act and the Regulations for a comprehensive understanding of the plant variety protection system in Malaysia.

${ }^{4}$ Regine Andersen and Tonya Winge, Success Stories From The Realization of Farmers Rights Related to Plant Genetic Resources For Food And Agriculture (The Fridtjof Nansen institute 2004). 
because it enables farmers to claim special forms of intellectual property rights over their own traditional plant varieties. ${ }^{5}$ The uniqueness of India's PPVFR 2001 lies in its innovative provisions towards safeguarding the rights of its farming communities. By combining the features of plant breeders' rights as enumerated in the International Convention for the Protection of New Varieties of Plants (UPOV Convention) and elements of Convention on Biological Diversity (CBD) and the FAO Treaty, the PPVFR 2001 is more advanced and comprehensive from other legislations at it recognises the various rights of farmers' parallel to those of the commercial breeders. ${ }^{6}$ India's PPVFR has been described by Dang and Goel as a sui generis piece of legislation representing the "vulnerabilities and ambitions of developing nations". ${ }^{7}$

The Organization of African Union (OAU), renamed the African Unity chose to develop its own sui generis law, the AU Model Law as an alternative system to those of intellectual property rights as required by TRIPS. The Model Law addresses not only the IP requirements of TRIPS over genetic resources but highlighted the CBD principle of states' sovereign rights over their biological diversity through a benefit sharing regime. ${ }^{8}$ This legislation provides a basis for individual African countries to prepare their domestic PVP legislation focusing on four major cornerstones of sustainable PGR use, namely access to biological resources, community rights, farmers' rights and plant breeders' rights. ${ }^{9}$ Zerbe, discussing the development of the Model Law contends that the legislation is an

${ }^{5}$ Anitha Ramanna, Background Study No. 4 - Farmers' Rights in India: A Case Study, FNI Report 6/2006 (The Fridtjof Nansen Institute 2006).; Harbir Singh, 'Plant Variety Protection and Food Security: Lessons for Developing Countries' (2007) 12 Journal of Intellectual Property Rights.[392].

6 Karine Peschard, 'Farmers' Rights and Food Sovereignty: Critical Insights from India' (2014) 41 Journal of Peasant Studies. The same has been concluded byAnshu Pratap Singh and Padmavati Manchikati, 'Sui Generis IPR Laws Vis-à-Vis Farmers' Rights in Some Asian Countries: Implications under the WTO’ (2011) 16 Journal of Intellectual Property Rights.[110].

7 Rohan Dang and Chandni Goel, 'Sui Generis Plant Variety Protection: The Indian Perspective' (2009) 1 American Journal of Economics and Business Administration.[308].

${ }^{8}$ Noah Zerbe, 'Biodiversity, Ownership and Indigenous Knowledge: Exploring Legal Frameworks for Community, Farmers and Intellectual Property Rights in Africa' (2005) 53 Ecological Economics.[495].

${ }^{9}$ Harbir Singh (n 6).[392]. 
initiative of the African countries in developing a comprehensive legal structure encompassing "aspects of biodiversity management, intellectual property rights and protection of indigenous knowledge". ${ }^{10}$

India, Malaysia and AU group of countries have relied on agriculture as a source for their economic growth either in the past or at present. With quite a substantial population of farmers, both subsistence and commercial, these groups of countries have endeavored FAO Treaty 2004 as follows "that the past, present and future contributions of farmers in all regions of the world, particularly those in centres of origin and diversity, in conserving, improving and making available these resources, is the basis of Farmers' Rights".

Article 9.1 of the FAO Treaty 2004 states:

"The contracting Parties recognise the enormous contribution that local and indigenous communities and farmers of all regions of the world, particularly those in the centre of origin and crop diversity, have made and will continue to make for the conservation and development of plant genetic resources which constitute the basis of food and agriculture production throughout the world".

Article 9.2 of the same Treaty put forward subject matters which are included under Farmers' Rights concept as follows:

(a) protection of traditional knowledge relevant to plant genetic resources for food and agriculture;

(b) the right to equitably participate in the sharing of benefits arising from the utilisation of plant genetic resources for food and agriculture; and

(c) the right to participate in making decisions, at the national level, on matters related to the conservation and sustainable use of plant genetic resources for food and agriculture.

Article 9.3 states that "nothing in this Article shall be interpreted to limit any rights that farmers have to save, use, exchange and sell farm-saved seed".

This working definition under Article 9 establishes a common ground of understanding for all parties involved in realising Farmers' Rights concept, while

${ }^{10}$ Noah Zerbe (n 10).[494]. 
at the same time allowing countries to adopt measures to do so according to their own priorities and needs. ${ }^{11}$ The definition also emphasis on the recognition ${ }^{12}$ of contributions and conservation effort made by traditional farmers especially from the genetic rich countries, in developing and maintaining PGRFA. However, the specific nature of these bundle of rights and the standard for its enforcement are left to the discretions of each national government. Article $9.2^{13}$ and 9.3 of the International Treaty 2001, provides the responsibility to each national governments, to carry out appropriate methods in harmony with their respective national laws in realising the Farmers' Rights concept.

\section{Right to Equitably Participate in Sharing Benefits}

Adhikari proposes benefit sharing to be - sharing of benefits either in monetary or non-monetary forms or a combination thereof, due to the commercial use of resources between the owner-provider and the receiver-user of those resources. The emphasis on the right of farmers to share benefits arising from the utilisation of PGRFA was highlighted in the early 1980s, by biodiversity-rich countries, mostly as the providers of the resources against the technology-rich countries as the users of these resources. Intellectual property rights such as plant breeder's rights and patents facilitated access to PGRFA and generate significant amount of profits for the breeders and seed companies through exclusive rights of marketing, control and distribution of new plant varieties, however failed to address the contribution of the farmers with regards to sharing of benefits arising out of the

\footnotetext{
${ }^{11}$ Regine Andersen and Tone Winge, The Plant Treaty and Farmers' Rights: Implementation Issues for South Asia (South Asia Watch on Trade, Economics \& Environment (SAWTEE) (2009).; Regine Andersen, The History of Farmers'Rights: A Guide to Central Documents and Literature, FNI Report 8/2005 (2005).; Regine Andersen, Realising Farmers' Rights under the International Treaty on Plant Genetic Resources for Food and Agriculture, Summary of Findings from the Farmers' Project, Phase 1, FNI Report 11/2006. (2006).

${ }^{12}$ Under the Farmers' Right concept, recognition can be either monetary or non-monetary; through benefit sharing mechanisms or by enabling the farmers to claim exclusive rights over the plant varieties they cultivate traditionally.

${ }^{13}$ Article 9.2 - "The Contracting Parties agree that the responsibility for realising Farmers' Rights, as they relate to plant genetic resources for food and agriculture, rests with national government."
} 
commercial uses of the PGRFA taken from them. ${ }^{14}$ This particular concern led to the call for protection of rights of farmers, local and indigenous communities under the FAO Treaty to counterbalance the exclusive rights provided under the intellectual property law framework to the holders. Article $8(\mathrm{j})$ of the CBD also provides for the equitable benefit sharing of benefits arising from the utilization of knowledge, innovations and practises of the local and indigenous communities on biological resources, with the approval and involvement of the holders of such knowledge. ${ }^{15}$ It is to be noted that CBD emphasis on utilisation of benefit sharing by way of bilateral basis. Comparatively, CBD provides the general framework on protection of biodiversity whereas the FAO Treaty addresses the specialised needs of PGRFA in the agriculture sector.

Article 9.2(b) of the FAO Treaty concerns the right of farmers to equitable benefit sharing as a measure to protect and promote Farmers' Rights. The benefit can be in the form of monetary or non-monetary benefits. One of the method for access and benefit sharing of genetic resources is through the multilateral system of the FAO Treaty and only of the specified PGRFA under it. ${ }^{16}$ Even though there is no specification on the types of benefit to flow to the farmers, guidance can be found in Article 13 of the FAO Treaty on benefits which are considered important. ${ }^{17}$ Among them are: ${ }^{18}$

i. facilitated access to seeds and propagating material, and related information;

ii access to and transfer of technology and exchange of information, by way of collaboration between farmers and breeders;

\footnotetext{
${ }^{14}$ Kamalesh Adhikari, Protection of Farmers' Right over Plant Varieties in Southeast Asian Countries (Southeast Asian Council for Food Security and Fair Trade (SEACON) 2008).[12-13].

${ }^{15}$ Article $8(\mathrm{j})$ of the CBD: Each Contracting Party shall, as far as possible and as appropriate: Subject to its national legislation, respect, preserve and maintain knowledge, innovations and practices of indigenous and local communities embodying traditional lifestyles relevant for the conservation and sustainable use of biological diversity and promote their wider application with the approval and involvement of the holders of such knowledge, innovations and practices and encourage the equitable sharing of the benefits arising from the utilization of such knowledge, innovations and practices.

${ }^{16}$ See Article 10.2 of the FAO Treaty \& Annexure I.

${ }^{17}$ IT/GB-3/09/inf.6 Add. 3, Third Session of the Governing Body, Food and Agriculture organization of the United Nations, Tunis, Tunisia, 1-5 June 2009, [10]

${ }^{18}$ See Article 13 of the FAO Treaty.
} 
iii. capacity building and sharing of monetary and other benefits arising from commercialisation.

Other non-monetary benefits include strengthening of farmers' seed systems, conservation activities, including local gene banks and enhancement on the accessibility and utilisation of farmers' varieties. The right to equitable benefit sharing can contribute in alleviating poverty as it would allow farmers to co-own and benefit from a new variety developed by modern plant breeders, when they contribute their traditional germplasm into the breeding activities.

Zerbe argues that the right of farmers to equitable benefit sharing form the usage of their genetic resources might be undermined as most national laws and policies to protect genetic resources emphasise on state sovereignty and government ownership over the materials. As such, the distribution of any royalties to the concerned farmers' community cannot be resolved practically due to ownership issues or might end up in insignificant monetary payment. He thus supports Lettington's view that though the benefit sharing component in Farmers' Rights is a positive right, it might not be able to function economically as its maintenance might outweigh the benefits to be received by the farming communities. In such an instance, a non-monetary benefit sharing arrangements might be more beneficial to the community as a whole. Mbote ${ }^{19}$ suggests that ensure that the benefit sharing arrangements benefit the community, these type of benefits should be received and their concrete operational mechanism should be ascertained earlier on in any agreement for benefit sharing between commercial breeders and concerned farming communities.

\section{Comparative Perspective on the Right to Equitably Participate in Sharing Benefits}

The Indian Act recognises the entitlement of farming or tribal communities that contributed to the development a new crop variety to equitable sharing of any benefits derived from it as provided under Section 39(1)(iii). The recognition

\footnotetext{
${ }^{19}$ Patricia Kameri- Mbote, 'Community, Farmers' and Breeders' Rights in Africa: Towards a Legal Framework for Sui Generis Legislation' (2003) 1 University of Nairobi Law Journal.[1-24].
} 
of their conservation and improvement efforts need to be included in the application in the manner listed out under Section 18(1)(e) of the PPVFR 2001. To ensure that farmers have the right to be rewarded and recognised for making available the PGRFA, Section 26(1) and (2) of the Act allows any application for benefit sharing from its citizen, governmental bodies or firms established in the country before registering a new variety. Upon the determination of the amount of benefit sharing by the relevant authority, the claimant is entitled to claim for the amount from the National Gene Fund which is set up under section 45 to distribute the benefit.

Malaysia does not have such provisions for benefit sharing to farmers as Indian PPVFR 2001. Section 12 (f) and (g) of PNVP 2004 mandate the requirements of prior written consent and supporting documents which are needed to be filed by an applicant when the applicant make use of any traditional varieties or genetic material. However, the Act is silent on the methods of benefit sharing. It is undeniable that small traditional communities are the early cultivators of plants for the agricultural sector and Article 1 of $\mathrm{CBD}^{20}$ highlights the concept of fair and equitable sharing of benefits in the use of genetic resources; however, such a mechanism for access and benefit sharing is not addressed in the PNVP 2004.

The AU Model Law under paragraph 6 of the Preamble ${ }^{21}$ declares that the state is to ensure fair and equitable sharing between resource providers (local communities) and commercial entrepreneurs on any benefits derived from the utilisation of biological resources. Local communities is regarded as a general owner of any form of biological resources and related knowledge and this has been

${ }^{20}$ Article 1 of CBD: The objectives of this Convention, to be pursued in accordance with its relevant provisions, are the conservation of biological diversity, the sustainable use of its components and the fair and equitable sharing of the benefits arising out of the utilization of genetic resources, including by appropriate access to genetic resources and by appropriate transfer of relevant technologies, taking into account all rights over those resources and to technologies, and by appropriate funding.

${ }^{21}$ It states: "Whereas, the State recognizes the necessity of providing adequate mechanisms for guaranteeing the just, equitable and effective participation of its citizens in the protection of their collective and individual rights and in making decisions which affect its biological and intellectual resources as well as the activities and benefits derived from their utilization." 
further reiterated in Part 1, paragraph (d) ${ }^{22}$ of the objectives of the AU Model Law. Another form of benefit sharing mechanism for the benefit of local communities exist under Article 12.2 of the AU Model Law wherein it provides sharing of benefits between State authority and respective local communities from earnings derived from the access and usage of biological resources and related knowledge. It is the responsibility of the State under Article $22.1^{23}$ to ensure that at least 50 per cent of the benefits received are shared equitably by the local communities irrespective of gender. Article 26 (b) of the AU Model Law refers specifically to benefit sharing to farming communities for any benefits derived from the utilisation of plant and animal genetic resources. Similar to India, the AU Model Law proposed the establishment of a Community Gene Fund under Article 66, as a focal point for receiving and subsequent distribution of such benefits to the local and farming communities concerned.

There is no mention of how farmers are supported and recognised for their role in conserving and developing crop genetic diversity, and how their rights to share benefits derived from the use of their varieties are ensured under Malaysian PNPV in comparison to Indian law and AU Model Law. In the absence of appropriate benefits sharing regulations in place, local communities might end always at the losing end. The Act as a result does not adequately protect against bio piracy or unauthorised usage of plant genetic resources.

\section{Conclusion}

The above comparison reveals that the PVP laws in place in India and Malaysia are indeed sui generis law by providing more recognition on the rights of their farming communities. PVP legislation in both countries is already geared

\footnotetext{
${ }^{22}$ Part 1: Objectives - The specific objectives of this legislation shall be to: (d) promote appropriate mechanisms for a fair and equitable sharing of benefits arising from the use of biological resources, knowledge and technologies;

${ }^{23}$ Article 22.1: The State shall ensure that at least fifty per cent of benefits provided for in Article 12 (2) shall be channelled to the concerned local community or communities in a manner, which treats men and women equitably.
} 
towards realisation of the four core concepts as measures towards realisation of Farmers' Rights concept as mentioned in Article 9 of FAO Treaty. The provisions of AU Model Law, are more congruent with the purpose of CBD and the FAO Treaty, nonetheless the AU Model Law is regional in nature, is still in its infancy stage and in the process of being adopted by the African states. Malaysian PNPV 2004 is similar to India's PPVFR 2001 which is already a decade old and was tailored specific to meet the country's specific farming communities' needs. Regardless of these facts, all three legal frameworks incorporated certain elements of Farmers' Rights concept resulting in it being as sui generis frameworks on plant variety rights.

Malaysia's protection on the rights of farmers to share in utilisation of benefit in the usage of PGRFA under its plant variety law could be further enhanced to ensure protection for the farmers. By setting up a specialised body to monitor and distribute the benefits to farmers, such as the National Gene Fund of India, there is a higher chance that the local farmers would be benefiting from the commercialization of their PGRFA. One the methods by which actual equitable benefit sharing can be realized is by way of requiring those seeking to use general domestic plant and varieties developed by farmers, for commercial purposes to apply for a special permit or license before doing so. The permit or license shall be obtained through the Department of Agriculture of Malaysia and may be issued subject to few conditions; among others a provision of equitable benefit sharing or an agreement to that effect, between the users and the farming communities from which the genetic resources are obtained. Such an agreement can be regulated by the Department of Agriculture and any royalties or profit-sharing from it, can be utilized for the support of local farming communities for their breeding and development progress.

On this note, the new law passed recently on access and benefit sharing that is the Access to Biological Resources and Benefit Sharing Act 2017 (Act 795) would provide farmers-particularly small farmers with additional legal justifications for farmers to exercise their right to equitable sharing of benefits. The Preamble to the Act clearly spells out that it is an instrument to implement the goals of CBD in dealing on the issue of access of biological resources and sharing of benefits 
arising out of its commercialization. ${ }^{24}$ The Act is a supplement to the current laws in Malaysia on access and sharing of benefits on biological resources and section 6 of the Act clearly stated that it will not affect the rights of small farmers to practise seed saving. From a cursory reading of the Act, it seems to strengthen and regulate on the issue of access and sharing of benefit from the commercialization of biological resources for the holders of these resources and protection against biopiracy. This is a most lauded effort by the government of Malaysia to prevent further misappropriations of biological resources but being very recent, the Act is yet to be tested in its effectiveness to regulate access and benefit sharing of biological resources in Malaysia.

\section{Bibliography}

Anitha Ramanna, Background Study No. 4 - Farmers'Rights in India: A Case Study, FNI Report 6/2006 (The Fridtjof Nansen Institute 2006).

Anshu Pratap Singh and Padmavati Manchikati, 'Sui Generis IPR Laws Vis-àVis Farmers' Rights in Some Asian Countries: Implications under the WTO' (2011) 16 Journal of Intellectual Property Rights.

Harbir Singh, 'Plant Variety Protection and Food Security: Lessons for Developing Countries' (2007) 12 Journal of Intellectual Property Rights.

Ida Madieha Abdul Ghani Azmi, 'The Protection of Plant Varieties in Malaysia' (2004) 7 Journal of World Intellectual Property.

Kamalesh Adhikari, Protection of Farmers'Right over Plant Varieties in Southeast Asian Countries (Southeast Asian Council for Food Security and Fair Trade (SEACON) 2008).

Karine Peschard, 'Farmers' Rights and Food Sovereignty: Critical Insights from India' (2014) 41 Journal of Peasant Studies.

Noah Zerbe, 'Biodiversity, Ownership and Indigenous Knowledge: Exploring Legal Frameworks for Community, Farmers and Intellectual Property Rights in Africa' (2005) 53 Ecological Economics.

${ }^{24}$ See Access to Biological Resources and Benefit Sharing Act 2017 (Act 795) of Malaysia which was passed in August 2017 recently. 
Patricia Kameri- Mbote, 'Community, Farmers' and Breeders' Rights in Africa: Towards a Legal Framework for Sui Generis Legislation' (2003) 1 University of Nairobi Law Journal.

Regine Andersen, The History of Farmers'Rights: A Guide to Central Documents and Literature, FNI Report 8/2005 (2005).

- Realising Farmers' Rights under the International Treaty on Plant Genetic Resources for Food and Agriculture, Summary of Findings from the Farmers' Project, Phase 1, FNI Report 11/2006. (2006).

Regine Andersen and Tone Winge, The Plant Treaty and Farmers' Rights: Implementation Issues for South Asia (South Asia Watch on Trade, Economics \& Environment (SAWTEE) (2009).

Regine Andersen and Tonya Winge, Success Stories From The Realization of Farmers Rights Related to Plant Genetic Resources For Food And Agriculture (The Fridtjof Nansen institute 2004).

Rohan Dang and Chandni Goel, 'Sui Generis Plant Variety Protection: The Indian Perspective' (2009) 1 American Journal of Economics and Business Administration.

HOW TO CITE: Murshamshul Kamariah Musa, Abdul Majid Tahir Mohamed and Abdul Majid Hafiz Mohamed, 'Integrating Farmers' Rights to Equitable Benefit Sharing Into the Malaysian Plant Variety Law: Learning from Others' (2019) 34 Yuridika. 
--This page is intentionally left blank-- 